\title{
Astrocyte and Muscle-Derived Secreted Factors Differentially Regulate Motoneuron Survival
}

\author{
Anna R. Taylor, ${ }^{1}$ David J. Gifondorwa, ${ }^{2}$ Jason M. Newbern, ${ }^{1}$ Mac B. Robinson, ${ }^{1}$ Jane L. Strupe, ${ }^{1}$ David Prevette, ${ }^{1}$ \\ Ronald W. Oppenheim, ${ }^{1,2}$ and Carolanne E. Milligan ${ }^{1,2}$ \\ ${ }^{1}$ Department of Neurobiology and Anatomy, and 2 Program in Neuroscience, Wake Forest University School of Medicine, Winston-Salem, North Carolina \\ 27157
}

During development, motoneurons (MNs) undergo a highly stereotyped, temporally and spatially defined period of programmed cell death (PCD), the result of which is the loss of $40-50 \%$ of the original neuronal population. Those MNs that survive are thought to reflect the successful acquisition of limiting amounts of trophic factors from the target. In contrast, maturation of MNs limits the need for target-derived trophic factors, because axotomy of these neurons in adulthood results in minimal neuronal loss. It is unclear whether MNs lose their need for trophic factors altogether or whether, instead, they come to rely on other cell types for nourishment. Astrocytes are known to supply trophic factors to a variety of neuronal populations and thus may nourish MNs in the absence of target-derived factors. We investigated the survival-promoting activities of muscle- and astrocyte-derived secreted factors and found that astrocyteconditioned media (ACM) was able to save substantially more motoneurons in vitro than muscle-conditioned media (MCM). Our results indicate that both ACM and MCM are significant sources of MN trophic support in vitro and in ovo, but only ACM can rescue MNs after unilateral limb bud removal. Furthermore, we provide evidence suggesting that MCM facilitates the death of a subpopulation of MNs in a $75^{\mathrm{NTR}}$ - and caspase-dependent manner; however, maturation in ACM results in MN trophic independence and reduced vulnerability to this negative, pro-apoptotic influence from the target.

Key words: p75NTR; programmed cell death; amyotrophic lateral sclerosis; apoptosis; caspase; SMA; trophic

\section{Introduction}

The interaction of motoneurons (MNs) with their target (muscle) has been extensively investigated and is thought to be critical for the regulation of programmed cell death (PCD) of MNs during development. During PCD, which occurs between embryonic day 5 (E5) and E12 in the chick embryo, $40-50 \%$ of the MNs that are originally born die by a process thought to be the direct result of a competition for a limited supply of target-derived trophic support (Cunningham, 1982; Oppenheim, 1991; Sendtner et al., 2000; Yuan and Yankner, 2000). Classically, the role of the target has been demonstrated by experimental manipulation of its size. Extirpation of a developing limb at E2.5 results in an amplification of PCD ipsilateral to the lesion, without affecting development of the contralateral side (Oppenheim et al., 1978; Caldero et al., 1998). Similar findings are seen when the target size is reduced by genetic manipulation or somite removal (Phelan and Hollyday, 1991; Grieshammer et al., 1998; Kablar and Rudnicki, 1999). These findings are complimented by studies that show that the addition of a supernumerary limb increases the number of sur-

Received Sept. 11, 2006; revised Nov. 14, 2006; accepted Dec. 11, 2006.

This work was supported by National Institutes of Health Grants NS036081 and by funds from the WFUSM Brian White ALS Foundation (C.E.M.). We thank Dr. David Riddle for his review and editorial comments.

Correspondence should be addressed to Carol E. Milligan, Department of Neurobiology and Anatomy, Wake Forest University School of Medicine, Winston-Salem, NC 27157. E-mail: milligan@wfubmc.edu.

J. M. Newbern's present address: Neuroscience Center, University of North Carolina at Chapel Hill, Chapel Hill, NC 27599.

DOI:10.1523/JNEUROSCI.4947-06.2007

Copyright $\odot 2007$ Society for Neuroscience $\quad$ 0270-6474/07/270634-11\$15.00/0 viving MNs on the ipsilateral side (Hollyday and Hamburger, 1976).

The survival-promoting benefits of the target muscle have been documented extensively. Skeletal muscle extract (MEx), a fractionated cytosolic homogenate of the target muscle, has been identified as a potent source of trophic support for MNs both in vitro and in vivo (Smith and Appel, 1983; Henderson et al., 1984; Oppenheim et al., 1988; Milligan et al., 1994). Similar to MEx, media conditioned by muscle cells and myotubes promote neurite outgrowth and MN survival both in vitro and in vivo (Henderson et al., 1981; Calof and Reichardt, 1984; Eagleson and Bennett, 1986; Petruzzelli and Hughes, 1989; Oppenheim et al., 1993; Arce et al., 1998). Both of these protein mixtures contain multiple putative target-derived trophic factors that have been identified to rescue MNs both in vitro and in vivo [e.g., BDNF, neurotrophin 3 (NT3), NT4/5, glial cell line-derived neurotrophic factor (GDNF), CNTF, HGF (hepatic growth factor), EGF (epidermal growth factor), FGF, IGF-1, and cardiotrophin-1 among others] (Oppenheim, 1996; Henderson et al., 1998; Sendtner et al., 2000). MNs are a unique neuronal population in that they not only require multiple factors to maximally sustain their survival, but they are insensitive to the prototypical neurotrophin nerve growth factor (NGF), because they are deficient in the tyrosine receptor kinase A (TrkA) receptor (Oppenheim et al., 1993; Yan et al., 1993; Nishi, 1994; Oppenheim, 1996; Sendtner et al., 1996; Curtis et al., 1998; Gould and Oppenheim, 2004; Ricart et al., 2006). In fact, it has become clear that NGF can induce apoptosis 
of MNs (as well as other neuronal populations) through its interaction with p75 ${ }^{\text {NTR }}$ (Rabizadeh et al., 1993; von Bartheld et al., 1994; Frade et al., 1996; Sedel et al., 1999; Terrado et al., 2000; Barbeito et al., 2004; Pehar et al., 2004). Furthermore, although p75 NTR is highly expressed during early development, it is postnatally downregulated but is often reactivated after injury or disease implying multiple, context-dependent functions for this receptor (Ernfors et al., 1989; Rabizadeh et al., 1993; Dowling et al., 1999).

Although the target has been extensively investigated as a principle source of trophic support for developing MNs, its requirement for the maintenance of MNs diminishes with age (Crews and Wigston, 1990; Kuno, 1990; Lowrie and Vrbova, 1992; Houenou et al., 1994). The number of MNs that die as a result of axotomy, limb amputation, and nerve crush is diminished as the organism ages, although it is unclear whether MNs become trophic-independent or, if with age, they come to depend on alternative sources of trophic support (Snider and Thanedar, 1989; Crews and Wigston, 1990). Numerous other putative trophic sources exist, including glia (e.g., Schwann cells and astrocytes), afferents, and components of the extracellular matrix (Okado and Oppenheim, 1984; Eagleson et al., 1985; Furber et al., 1987; Yin et al., 1994; Riethmacher et al., 1997; Arce et al., 1998; Wong et al., 1999). Astrocytes represent a significant, yet underappreciated, cellular population in the nervous system that contributes to numerous developmental processes. These cells produce a variety of trophic factors that may sustain neuronal survival in the absence of better studied sources of trophic support and after injury (Muller et al., 1995; Lafon-Cazal et al., 2003). Although astrocytes support the survival of MNs in vitro and rescue MNs from injury after deafferentation in vivo, their ability to compensate for loss of the target is less clear (Eagleson et al., 1985; Yin et al., 1994).

We investigated the ability of secreted factors produced by limb muscle cells and by spinal cord astrocytes to promote MN survival in vitro, during the period of naturally occurring PCD in vivo, and after unilateral LBR. Whereas both astrocytes and muscle cells produce factors that significantly rescue MNs from death, we show that muscle-conditioned media (MCM) also contains factors that negatively impinge on MN survival in a p75 ${ }^{\mathrm{NTR}}$ dependent manner. Furthermore, when MNs are differentiated in the presence of astrocytes, they are no longer susceptible to this negative influence of the target.

\section{Materials and Methods}

MN cultures. MNs were cultured from the lumbar spinal cords of E5E5.5 chick embryos as described previously (Milligan et al., 1994; Taylor et al., 2003; Newbern et al., 2005). Briefly, spinal cords were digested in $0.05 \%$ trypsin, dissociated, layered onto a $5 \%(\mathrm{v} / \mathrm{v})$ Iodixanol (Optipep) density gradient, and centrifuged at $900 \times g$. The $\mathrm{MN}$-enriched interface layer was collected, diluted in culture media, and centrifuged at $700 \times g$ over a $4 \%$ BSA cushion. The pellet was collected and resuspended in complete media as described previously (Taylor et al., 2003; Newbern et al., 2005). Cells were plated on poly-ornithine/laminin-coated 48-well plates at a density of $100 \mathrm{cells} / \mathrm{mm}^{2}$.

In acute experiments, cultures were experimentally treated within $1 \mathrm{~h}$ of plating. For experiments in established cultures, cells were plated in complete media with $20 \mu \mathrm{g} / \mathrm{ml}$ astrocyte-conditioned media (ACM) or muscle extract [prepared as described by Oppenheim et al. (1988)]. After $2 \mathrm{~d}$ in culture, cells were rinsed six times with L15 and fresh, complete media containing $20 \mu \mathrm{g} / \mathrm{ml}$ of either ACM or MCM was added. Antibodies and trophic factors used to treat cultures were anti-NGF $2.5 \mathrm{~S}(\mathrm{~N}-$ 6655; Sigma, St. Louis, MO), anti-p75 ${ }^{\mathrm{NTR}}$ (Chemicon, Temecula, CA), anti-GDNF (MAB212), anti-GFR $\alpha 1$ (AF560; R \& D Systems, Minneapolis, MN), anti-BDNF (AB1513P), anti-NT3 (AB1780SP; Chemicon), mouse NGF 2.5S (Alomone Labs, Jerusalem, Israel), and caspase inhibitors were z-IETD-FMK and z-DEVD-FMK (R \& D Systems).

Survival was determined by treatment of MNs with $1 \mu \mathrm{M}$ calcein AM (Invitrogen, San Diego, CA), a cell-permeable, fluorescent indicator of living cells. After treatment, cells were counted in two perpendicular diameters of the culture well at $20 \times$. Cells were $\sim 90 \%$ pure based on the nuclear localization of the immunocytochemical marker, Islet-1 (Ericson et al., 1992; Milligan et al., 1994). Each condition was performed in triplicate and replicated in at least three different cultures.

Astrocyte cultures. Astrocytes were isolated from E12 chick lumbar spinal cords as described previously with modifications (Levison and McCarthy, 1991). After dissection, spinal cords were subjected to a brief $0.05 \%$ trypsin digestion and dissociated. The resulting cell suspension was centrifuged over a $4 \%$ BSA cushion to reduce detritus, and the recovered cell pellet was plated onto T-75 flasks in growth media containing DMEM-F12 media (Invitrogen) supplemented with 10\% fetal bovine serum, penicillin-streptomycin, and fungizone. Media were replaced after $4 \mathrm{~d}$ in culture and every $2 \mathrm{~d}$ thereafter. After reaching confluency, contaminating cells were removed by shaking flasks overnight at 260 $\mathrm{rpm}$. Remaining cells were detached with $0.25 \%$ trypsin and plated at a density of 500 cells $/ \mathrm{mm}^{2}$ in defined media (DMEM-F12 plus G5 supplement) (Invitrogen) to promote differentiation (Michler-Stuke and Bottenstein, 1982). Cultures were routinely monitored for purity and were not used unless they were $\geq 99 \%$ GFAP (Dako, High Wycombe, UK) immunoreactive.

Muscle cultures. Muscle cells were isolated from E11 chick hindlimb as described previously, with minor modifications (Neville et al., 1998; Robinson et al., 2005). Muscle cells were grown to confluence in serum containing growth medium until myotubes were observed and then maintained in serum-free differentiation medium for the duration of the culture.

Preparation of ACM and MCM. Astrocytes and muscles were cultured and differentiated as described above. Cultures were maintained and fed every 3-4 d. After reaching confluency, cultures were switched to a basal media (DMEM-F12 or DMEM containing penicillin-streptomycin and fungizone) for $48 \mathrm{~h}$. Media were collected from cultures and centrifuged at $400 \times g$ to remove free cells and membrane debris. Proteins from $\mathrm{CM}$ were precipitated with a $25-75 \%$ fraction of $\left(\mathrm{NH}_{4}\right)_{2} \mathrm{SO}_{4}$ and collected after centrifugation at $20,800 \times g$ for $1 \mathrm{~h}$. Pellets were resuspended in MilliQ water and dialyzed against PBS, pH 7.4. After dialysis, the protein solution was filter-sterilized, assayed for protein concentration, and frozen at $-80^{\circ} \mathrm{C}$ until use.

Treatment of embryos. Fertilized eggs were windowed and treated from E6 to E9 with ACM, MCM, or PBS in $150 \mu$ l. At E10, embryos were decapitated, staged according to Hamburger and Hamilton (1951), and placed in Carnoy's fixative for $24 \mathrm{~h}$. The next day, the tissue was placed in $70 \%$ ethanol overnight, and then the lumbar region of the spinal cord was processed for paraffin embedding. Ten micrometer sections were stained with thionin as described previously (Chu-Wang and Oppenheim, 1978). Healthy and pyknotic motoneurons were counted in every 10th section (Clarke and Oppenheim, 1995). Dying motoneurons were counted if they were in the lateral motor column (LMC) and displayed a pyknotic profile (Clarke and Oppenheim, 1995).

Limb bud removals. Unilateral removal of the right limb bud was performed on E2.5, corresponding to stages 16-18 of the Hamburger-Hamilton stage series (Hamburger and Hamilton, 1951), using surgical methods described previously (Hamburger and Hamilton, 1951; Oppenheim et al., 1978; Caldero et al., 1998). Embryos were treated with ACM, MCM, or PBS from E3 to E7 as described above and killed on E8. Only those embryos later observed to have a complete absence of the leg and pelvic girdle were used for analysis. Because unilateral LBR in the chick has no effect on the development of contralateral sensory or motor neurons (Oppenheim et al., 1978), this side was used as an internal control. Processing and counting of MNs was performed as described above.

Detection of caspase activity. MNs were collected in cell extraction buffer (50 mм HEPES, pH 7.0, 1 mм EDTA, 50 mм KCl, 2 mм $\mathrm{MgCl}_{2}, 1$ $\mu \mathrm{g} / \mathrm{ml}$ leupeptin, $1 \mu \mathrm{g} / \mathrm{ml}$ aprotinin, and $1 \mathrm{~mm}$ PMSF), sonicated, cleared by centrifugation, and assayed for protein content. Caspase 3/7 activity was measured using the Apo-One Homogenous Caspase 3/7 assay (Pro- 
mega, Madison, WI) according to a modified manufacturer protocol. Caspase 8 activity was measured using the Caspase-Glo 8 Assay (Promega). One microgram of protein in a final volume of $20 \mu \mathrm{l}$ was analyzed with an equal volume of caspase substrate in supplied buffer. The resulting signal was read using a spectrofluorometer at $488 \lambda / 535 \lambda$ (caspase $3 / 7$ ) or a luminometer (caspase 8). Data were transformed by calculating the proportional change relative to untreated controls.

\section{Results}

MCM and ACM support the survival of acutely isolated MNs

The target is considered to be the primary, although not sole, source of trophic support for MNs during development. We therefore examined the MN survivalpromoting abilities of secreted factors from this source, as well as from spinal cord astrocytes. MNs were treated with increasing doses of ACM and MCM, and their viability was determined after $72 \mathrm{~h}$. At doses $>10 \mu \mathrm{g} / \mathrm{ml}$, ACM promoted significant $\mathrm{MN}$ survival compared with deprived cells $\left({ }^{*} p<0.05,10 \mu \mathrm{g} / \mathrm{ml}\right.$ vs deprived; ${ }^{* *} p<0.001,20,40$, and $80 \mu \mathrm{g} / \mathrm{ml}$ vs deprived). Moreover, at higher doses (40 and $80 \mu \mathrm{g} / \mathrm{ml}$ ), ACM was superior to $\mathrm{MCM}$ at equal protein concentrations in its ability to rescue MNs from tropic factor deprivation (Fig. 1A,B). Although MCM was able to prevent the death of a significant number of MNs, this effect was less robust than ACM $\left({ }^{*} p<0.05,40 \mu \mathrm{g} / \mathrm{ml}\right.$ vs deprived; ${ }^{* *} p<0.01,20 \mu \mathrm{g} / \mathrm{ml}$ vs deprived). The degree of survival promoted by MCM was similar to that seen previously with MEx (prepared from chick hindlimb homogenates), a potent source of trophic support for MNs (Fig. $1 B$ ) $(\mathrm{Op}$ penheim et al., 1988; Bloch-Gallego et al., 1991; Milligan et al., 1994). Furthermore, at higher concentrations ( $\geq 80 \mu \mathrm{g} / \mathrm{ml})$, the survival-promoting abilities of MCM were diminished (Fig. $1 B$ ), a phenomenon similar to that seen with MEx-treated MNs (Henderson et al., 1984) (C.E.M., unpublished observations). By analyzing ACM-, MCM-, and MEx-treated cultures with an antibody against the MN-specific marker, Islet-1, we were able to verify that the rescued cells were MNs (Ericson et al., 1992). The percentage of cells that were Islet- 1 positive did not differ significantly between conditions indicating that secreted factors from astrocytes and muscles rescue $\mathrm{MNs}$ and not another neuronal population present in the spinal cord (Fig. 1C).

ACM and MCM differentially regulate the survival of acutely isolated MNs through p $75^{\text {NTR }}$

MNs require multiple trophic factors to survive (Nishi, 1994; Oppenheim, 1996; Sendtner et al., 1996; Gould and Oppenheim,

$B$.

C.
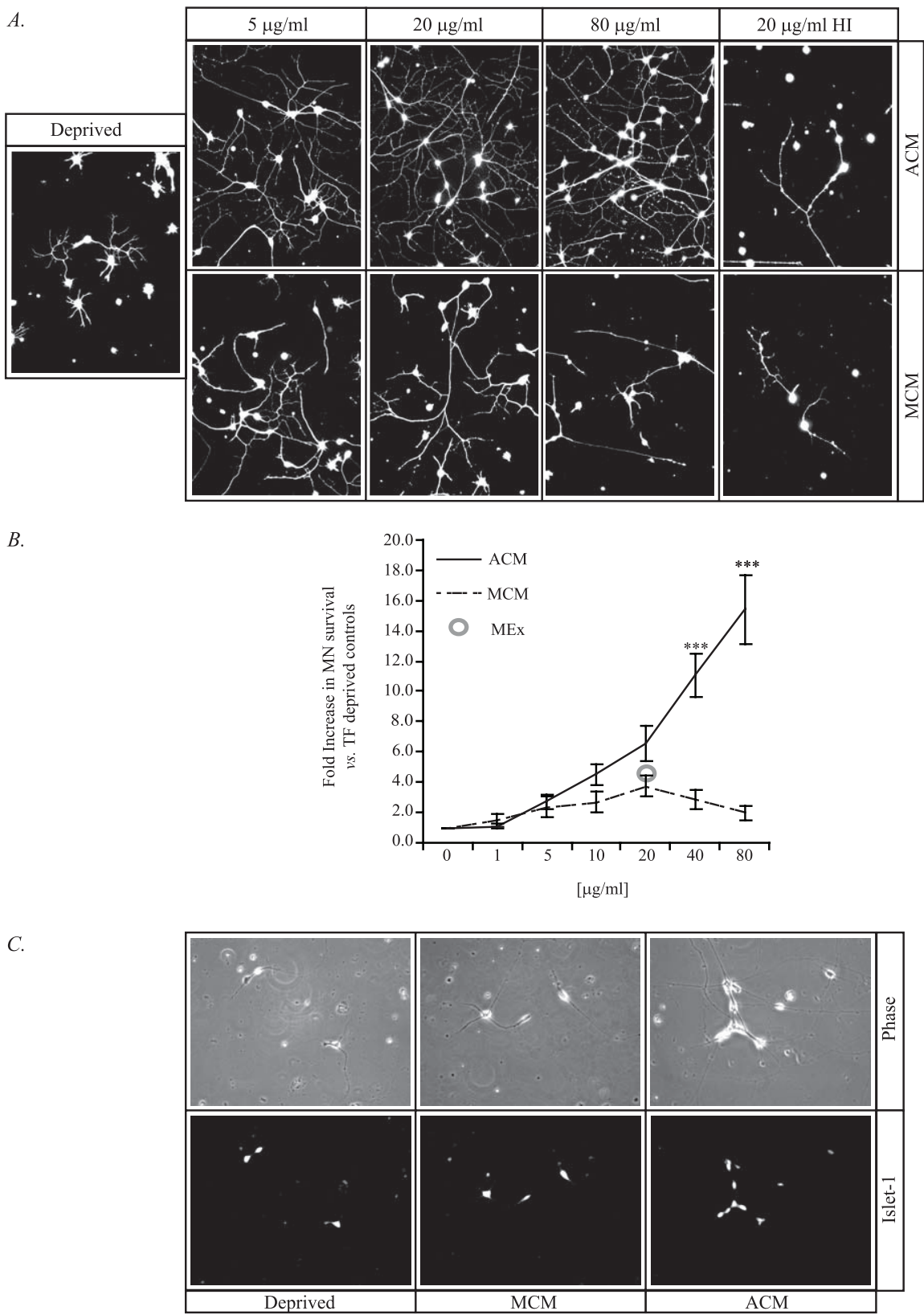

Figure 1. $A C M$ and MCM support the survival of acutely isolated MNs. $A$, Representative images depict calcein AM-labeled MNs cultured from plating with either ACM or MCM at indicated doses. After $72 \mathrm{~h}$, cultures were treated with $1 \mu \mathrm{m}$ calcein AM, and living cells were counted as described in Materials and Methods. Note the decrease in cell viability resulting from treatment using $80 \mu \mathrm{g} / \mathrm{ml}$ MCM. Also shown are representative images depicting trophic factor-deprived MNs and MNs treated with $20 \mu \mathrm{g} / \mathrm{ml}$ heat-inactivated ACM or MCM. Images are shown at $30 \times$. B, Quantification of cell counts described in $A$ indicate that 40 and 80 $\mu \mathrm{g} / \mathrm{ml}$ ACM promote significant survival when compared with MCM (*** $p<0.001$; ANOVA with Tukey-Kramer posthoc analysis). When compared with the trophic factor-deprived condition, ACM promoted significant MN survival at doses $>10 \mu \mathrm{g} / \mathrm{ml}$, whereas MCM promoted significantMN survival only at 20 and $40 \mu \mathrm{g} / \mathrm{ml}$ (see Results). The reference point indicates the level of survival observed when MNs are cultured with $20 \mu \mathrm{g} / \mathrm{ml}$ muscle extract. C, Representative images depict islet-1 immunoreactivity of TF-deprived, ACM- and MCM-treated cultures, indicating that the purity of MNs rescued by these factors was $>90 \%$.

2004). p $75^{\text {NTR }}$, a promiscuous receptor for multiple neurotrophins, is implicated in both the survival and death of MNs and is highly expressed in this population during development and in response to injury (McKay et al., 1996; Ferri et al., 1998; Wiese et al., 1999; Boyd and Gordon, 2001; Turner et al., 2003; Pehar et al., 2004; Cassina et al., 2005). Moreover, we verified p75 ${ }^{\text {NTR }}$ expression in MNs after treatment with ACM and MCM (data not shown). Therefore, we investigated the role of $\mathrm{p} 75^{\mathrm{NTR}}$ and one of its ligands, NGF, in MN survival after treatment with ACM and 


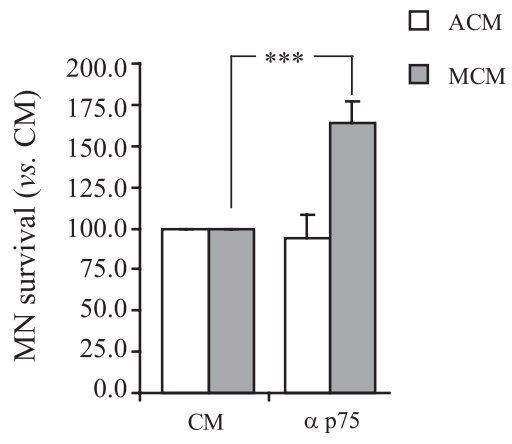

Figure 2. $\quad A C M$ and MCM differentially regulate the survival of acutely isolated MNs through p $75^{\text {NTR }}$. MNs were cultured from plating with MCM or ACM and antibodies that neutralize p $75^{\mathrm{NTR}}$ (1:500). Addition of this antibody to cultures treated with ACM did not alter the survivalpromoting activity of $A C M$, whereas the addition of the $775^{\mathrm{NTR}}$ neutralizing antibody to MCMtreated cultures results in an enhancement of MN survival by $65 \%\left({ }^{* * *} p<0.001\right.$; ANOVA with Tukey-Kramer post hoc test; $n=6$ ).

MCM. For these and all subsequent in vitro experiments, MNs were treated with $20 \mu \mathrm{g} / \mathrm{ml} \mathrm{ACM}$ or MCM unless otherwise indicated. Although the viability of MNs was unaffected when ACM- or MCM-treated cells were supplemented with recombinant NGF or with an NGF-neutralizing antibody (data not shown), treatment with a $\mathrm{p} 75^{\mathrm{NTR}}$-neutralizing antibody revealed a bifunctional role for this receptor. In ACM-treated cultures supplemented with anti-p $75^{\mathrm{NTR}}$, MN viability was unchanged relative to controls; however, treatment with MCM in combination with anti-p $75^{\text {NTR }}$ resulted in significant MN rescue (Fig. $2 A$ ). These data suggest that, although MCM likely contains multiple trophic factors, it also contains a factor (s) that adversely influences $\mathrm{MN}$ viability through $\mathrm{p} 75^{\mathrm{NTR}}$.

\section{MCM and ACM treatment results in differential caspase activation in acutely isolated MNs}

p $75^{\mathrm{NTR}}$ is a member of the tumor necrosis factor (TNF)/NGF superfamily of proteins. This protein family is characterized based on its homology with the TNF receptor and by the presence of an intracellular death domain. Many members of this family, including Fas/Apol, mediate apoptosis through the sequential activation of the death domain, recruitment of cytoplasmic adaptor proteins, and subsequent activation of caspase 8 (Raoul et al., 2000; Lambert et al., 2003). We therefore analyzed caspase 8 activity in MNs $24 \mathrm{~h}$ after treatment with MCM and ACM and observed that both resulted in a significant increase in activity (Fig. 3A). Inhibition of caspase 8 with z-IETD-fmk did not significantly enhance MCM- or ACM-induced MN survival (Fig. $3 B$ ), although caspase 8 activity in MCM-treated MNs was slightly reduced by p $75^{\mathrm{NTR}}$ blockade (Fig. $4 A$ ). Because, z-IETDfmk does not significantly rescue MNs from death induced by $\mathrm{MCM}$, and because caspase 8 activity is not significantly altered by blockade of $\mathrm{p} 75^{\mathrm{NTR}}$, it is unlikely that signaling through caspase 8 is the principle mechanism of death used by p $75^{\mathrm{NTR}}$ in MCM-treated MNs.

Although p $75^{\text {NTR }}$ signaling leads to apoptosis through caspase 8 activation in certain contexts, this is not a mechanism that is always used by this receptor (Della-Bianca et al., 2001; Wang et al., 2001; Troy et al., 2002; Giraud et al., 2005). The classic model for apoptotic death is that, after exposure to a death stimulus, apoptosome formation and caspase 3/7 activation ensues. MNs were therefore treated with MCM to determine the degree of caspase 3/7 activation. Treatment of MNs with ACM virtually eliminated caspase 3/7 activity; however, treatment of MNs with
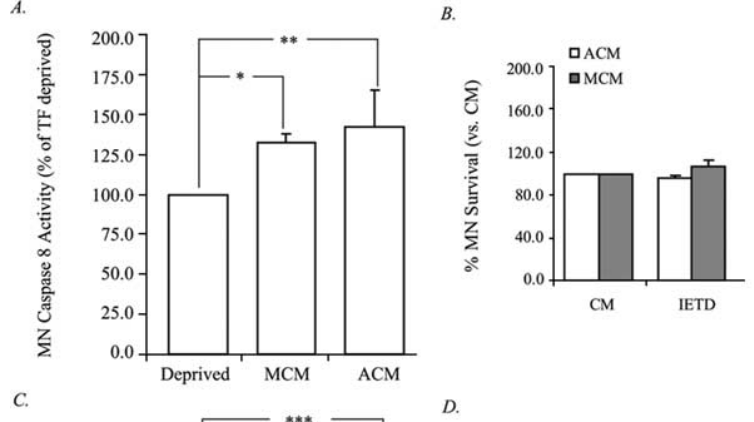

$D$.

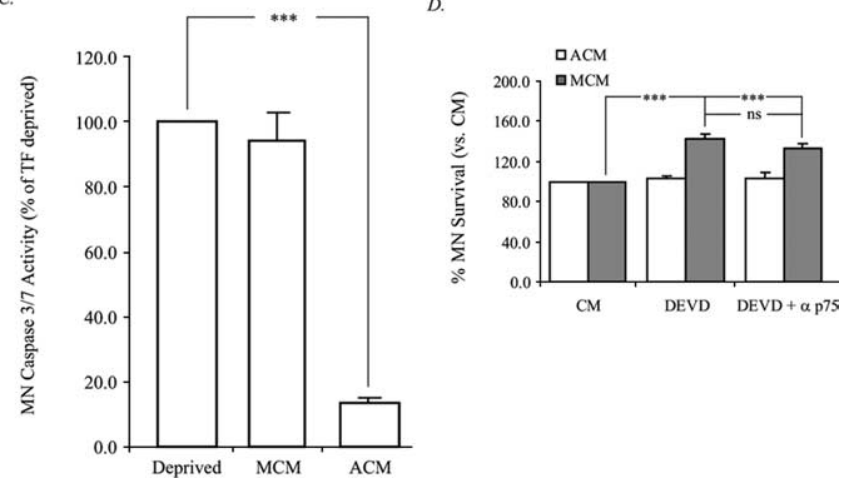

Figure 3. MCM and ACM treatment of acutely isolated MNs results in differential caspase activation and utilization. MNs were treated from plating with either ACM or MCM at $20 \mu \mathrm{g} / \mathrm{ml}$ and were assayed for caspase $8(\boldsymbol{A})$ and caspase $3 / 7(\boldsymbol{C})$ activity at $24 \mathrm{~h}$. Additionally, MN viability was determined after inhibition of caspase $8(\boldsymbol{B})$ and caspase $3 / 7$ alone or in combination with anti-p75 ${ }^{\mathrm{NTR}}(\boldsymbol{D}) . \boldsymbol{A}$, Treatment with both ACM and MCM resulted in the activation of caspase 8 relative to trophic factor-deprived condition. $\boldsymbol{B}$, Treatment of MNs with $10 \mu \mathrm{m}$ of the caspase 8 inhibitor, z-IETD-FMK (IETD), in the presence of ACM or MCM did not significantly affect viability. C, ACM significantly prevented the activation of caspase 3/7 observed after trophic factor deprivation, whereas $M C M$ was unable to do so, despite rescuing a significant number of cells. At no time analyzed was the caspase $3 / 7$ activity observed in MCM treated MNs significantly different from that observed in trophic factor-deprived cultures. D, ACM- or MCM-treated MNs were supplemented with the caspase 3/7 inhibitor z-DEVD-FMK alone or in the presence of anti-p $75^{\mathrm{NTR}}$, and viability was determined at $72 \mathrm{~h}$. Data are expressed as a percentage of trophic factor-deprived condition $(\boldsymbol{A}, \boldsymbol{C})$ or as a percentage of control CM $(\boldsymbol{B}, \boldsymbol{D})\left({ }^{*} p<0.05,{ }^{* *} p<0.01\right.$, ${ }^{* * *} p<0.001$; ANOVA with Tukey-Kramer post hoc analysis; $\left.n=5\right)$.

MCM resulted in a degree of caspase 3/7 activity similar to that seen in trophic factor deprived MNs, despite promoting a threefold to fourfold increase in survival (Figs. 1, 3C). In contrast to caspase 8 , inhibition of caspase $3 / 7$ with z-DEVD-fmk resulted in a significant rescue of MCM-treated MNs, a rescue that was not further enhanced by the presence of the $\mathrm{p} 75^{\mathrm{NTR}}$ blocking antibody (Fig. 3D). Additionally, blockade of $\mathrm{p} 75^{\mathrm{NTR}}$ reduced caspase $3 / 7$ activity (Fig. $4 B$ ), which together with our previous findings suggest that MCM promotes the death of a subset of MNs in a p $75^{\text {NTR }}$ - and caspase 3/7-dependent manner.

\section{ACM and MCM facilitate MN maintenance in matured MN cultures}

During spinal cord development, MNs interact with their target, and a proportion undergo naturally occurring PCD before the appearance of GFAP-immunoreactive astrocytes (Bignami and Dahl, 1975; Dahl and Bignami, 1975; Tapscott et al., 1981; Oppenheim et al., 1988). We thus sought to determine the developmental profile of MN susceptibility to adverse factors from the target and whether exposure to astrocyte-derived factors alters this susceptibility. For these experiments, MNs were established in ACM, MCM, or MEx for $2 \mathrm{~d}$, rinsed, and subsequently cultured in basal media or basal media containing ACM or MCM for 


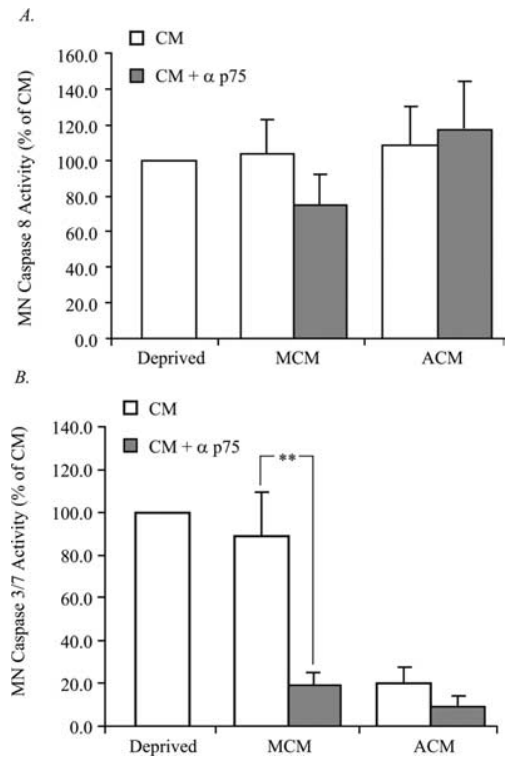

Figure 4. Blockade of $p 75^{\mathrm{NTR}}$ in MCM prevents activation of caspase $3 / 7$ but not caspase 8 . MNs were treated with the $p 75^{\mathrm{NTR}}$ antibody, protein extracts were collected, and caspase activity was analyzed. $\boldsymbol{A}$, Caspase 8 activity was measured in MCM- and ACM-treated MNs in response to $775^{\text {NTR }}$ inhibition. No change in the caspase 8 activity of ACM-treated MNs in response to $\mathrm{p} 75$ inhibition was observed; however, there was a slight, but statistically insignificant reduction in the caspase 8 activity of MCM-treated MNs in response to $\mathrm{p} 75^{\mathrm{NTR}}$ inhibition. B, Caspase $3 / 7$ activity was measured in MCM- and ACM-treated MNs in response to p $75^{\mathrm{NTR}}$ inhibition. No change in the caspase $3 / 7$ activity of ACM-treated MNs in response to p75 NTR inhibition was observed; however, the caspase $3 / 7$ activity of MCM-treated MNs in response to $\mathrm{p} 75^{\mathrm{NTR}}$ inhibition was reduced by $60 \%$. Data are expressed as a percentage of control CM ${ }^{* *} p<0.01$; ANOVA with Tukey-Kramer post hoc analysis; $\left.n=5\right)$.

the duration of the experiment. Viability was determined after $2 \mathrm{~d}$ in vitro (DIV) and again 3 d later at 5 DIV.

Initial treatment with ACM followed by trophic factor deprivation resulted in the maintenance of $75 \%$ of the $\mathrm{MNs}$ present at 2 DIV (Fig. 5A). In contrast, establishment of MNs in MCM or MEx for $2 \mathrm{~d}$, followed by trophic factor deprivation for the duration of the experiment, resulted in the maintenance of only 55 and $40 \%$ of MNs present at 2 DIV (Fig. 5A). These data suggest that ACM and MCM may serve not only survival-promoting functions but may also contain signals leading to MN trophic independence, which occurs at E12 in ovo (Houenou et al., 1994). Moreover, our data suggest that astrocyte-derived factors lead to a greater degree of trophic independence than target-derived factors (MCM and MEx).

To determine whether MNs established in ACM continue to be susceptible to pro-apoptotic influences from the target, MNs were initially treated with ACM for $2 \mathrm{~d}$, resupplied with either MCM or ACM at 2 DIV, and viability assessed at 5 DIV. Treatment in this manner resulted in equivalent survival of MCM- and ACM-treated MNs, suggesting that, under these circumstances in vitro, MCM is no longer deleterious to MNs, which may be attributable to reduced $\mathrm{MN}$ vulnerability after previous exposure to $\mathrm{ACM}$ (Fig. $5 B, C$ ).

\section{Alteration of $\mathrm{p} 75^{\mathrm{NTR}}$ function in ACM-matured MN cultures}

We used NGF and p $75^{\text {NTR }}$ neutralizing antibodies to determine whether the modified response of MNs to MCM after maturation with ACM involves p $75^{\mathrm{NTR}}$. Although neither NGF blockade nor exogenous NGF addition affected MN survival (data not shown), the blockade of $\mathrm{p} 75^{\mathrm{NTR}}$ in MCM- and ACM-treated cultures resulted in a decrease in MN viability at 5 DIV. Moreover, $\mathrm{p} 75^{\text {NTR }}$ was necessary to sustain the survival of $\sim 50 \%$ of the MN population (Fig. 6). These results suggest that early exposure of MNs to ACM alters their responsiveness to MCM, possibly by changing the way in which they use p $75^{\text {NTR }}$.

\section{ACM and MCM prevent MN PCD in ovo}

To determine whether ACM and MCM rescue MNs in ovo in a manner similar to that seen in vitro, we treated the highly vascularized chorioallantoic membrane of chick embryos with ACM and MCM during the period of naturally occurring MN PCD. Both healthy and pyknotic MNs were counted in the lumbar region of the E10 chick spinal cord according to previously established methods (Chu-Wang and Oppenheim, 1978). Similar to our findings in vitro, treatment with MCM at $6 \mu \mathrm{g} / \mathrm{ml}$ resulted in a significant increase in the number of healthy MNs (Fig. 7), as well as a significant decrease in the number of pyknotic profiles observed at E10 (data not shown). Higher doses of MCM did not show the same effect.

In contrast, treatment with ACM at $6 \mu \mathrm{g} / \mathrm{ml}$ had no effect on the number of either healthy (Fig. 7) or pyknotic (data not shown) MNs present; however, $60 \mu \mathrm{g} / \mathrm{ml}$ resulted in a significant increase in healthy (Fig. 7) MNs along with a significant decrease in pyknotic MNs (data not shown). Similar to MCM, high doses of ACM were unable to facilitate the rescue of additional MNs from PCD in ovo, suggesting that an optimal concentration of these protein mixtures is required for maximal survival. It is interesting to note that, in ovo, MCM rescues more MNs from PCD than ACM.

\section{ACM, but not MCM, rescues MNs from death after LBR}

Our data indicate that in vitro, target-naive MNs are markedly rescued by the presence of factors derived from astrocytes (Figs. $1,5)$. In contrast, in ovo, MNs that make target contact before the exposure of astrocyte-derived factors are rescued to a lesser degree (Fig. 7). Furthermore, MCM contributes to MN death in vitro in a p $75^{\mathrm{NTR}}$-dependent manner (Fig. 2). For these reasons, we asked whether astrocyte-derived factors would be more effective at rescuing MNs from death in the absence of the target in ovo. We performed unilateral LBR at E2.5 and treated embryos daily with MCM or ACM until they were killed at E8 and counted healthy and pyknotic MNs. Because this procedure does not affect the development of MNs contralateral to the injury, this side serves as an internal control (Oppenheim et al., 1978). In accordance with our previous findings, both MCM and ACM rescued a significant number of contralateral $\mathrm{MNs}$ from naturally occurring PCD (Figs. 7, 8 B), whereas after LBR, only ACM was able to promote a significant increase in the number of healthy (Fig. 8), and decrease in the number of pyknotic (data not shown), ipsilateral MNs.

\section{Discussion}

MNs are polytrophic, in that they require multiple factors to maximally sustain their survival (Nishi, 1994; Gould and Oppenheim, 2004). Furthermore, even in the presence of MEx, which contains numerous trophic factors, not all MNs are rescued from naturally occurring or induced PCD, a result that suggests two possibilities that are not mutually exclusive (Oppenheim et al., 1988). One possibility, that the target is not the sole source of $\mathrm{MN}$ trophic support, has been discussed extensively (Okado and Oppenheim, 1984; Eagleson et al., 1985; Furber et al., 1987; Yin et al., 1994; Riethmacher et al., 1997; Arce et al., 1998; Wong et al., 1999). Alternatively, the target may provide MNs with a complex balance of trophic and toxic signals that in sum, determine the 


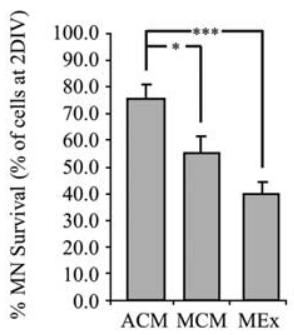

B.

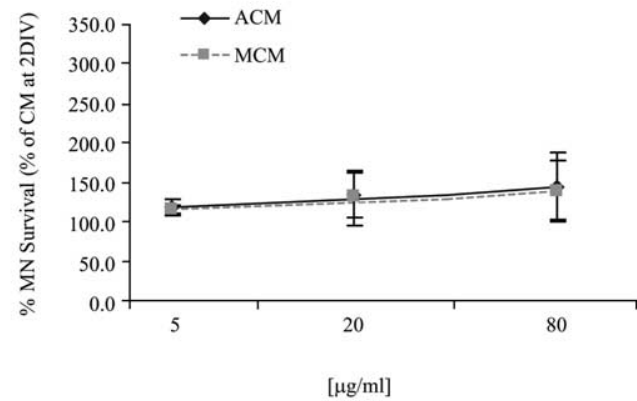

C.

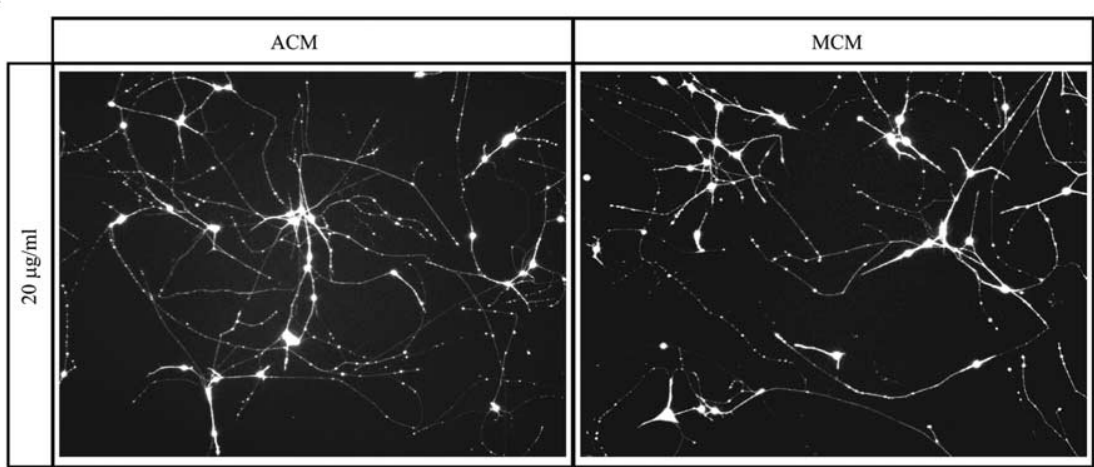

Figure 5. ACM and MCM facilitate MN maintenance in matured MN cultures deprived of trophic support. $\boldsymbol{A}$, MNs were cultured with $20 \mu \mathrm{g} / \mathrm{ml}$ ACM, MCM, or MEx for $2 \mathrm{~d}$. After 2 DIV, some cultures were counted, whereas the others were rinsed and were replaced with fresh media containing no additional trophic support. The remaining cells were counted $3 \mathrm{~d}$ later at 5 DIV. Data are expressed as the percentage of cells present at 2 DIV that remain at 5 DIV $\left({ }^{*} p<0.05,{ }^{* * *} p<0.001\right.$; ANOVA with Tukey-Kramer post hoc test; $n=8$ ). $B$, MNs were cultured from plating with $20 \mu \mathrm{g} / \mathrm{ml} \mathrm{ACM}$. At 2 DIV, cultures were counted, rinsed thoroughly, and replaced with fresh media containing $20 \mu \mathrm{g} / \mathrm{ml}$ of either ACM or MCM. At 5 DIV, cells were counted to determine the number of MNs remaining. Quantification of cell counts described in $\boldsymbol{A}$ indicate that both ACM and MCM are able to maintain MNs to an equivalent degree and that the death-inducing factor (s) present in MCM is incapable of exerting its function under these culture conditions. $\boldsymbol{C}$, Representative images of the conditions described in $\boldsymbol{B}$ depict calcein AM-labeled MNs 3 DIV after media were changed. Images were captured at $20 \times$.

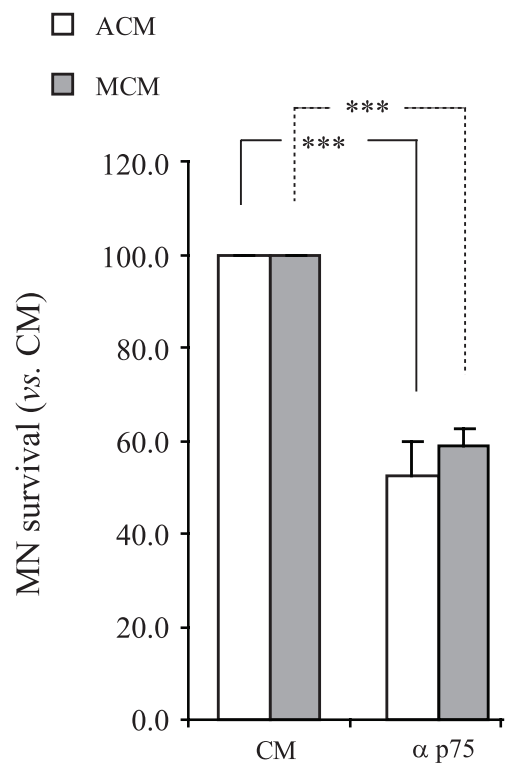

Figure 6. MCM and ACM induce similar responses through $\mathrm{p} 75^{\mathrm{NTR}}$ in mature MN cultures. MNs were cultured in ACM for 2 DIV, rinsed, and either MCM or ACM was reapplied in the presence of anti-p75 ${ }^{\text {NTR }}$, and viability was determined at 5 DIV. Treatment with anti-p75 $5^{\text {NTR }}$ resulted in a reduction in MN survival by $\sim 45 \%$ in response to both MCM and ACM $\left({ }^{* * *} p<\right.$ 0.001; ANOVA with Tukey-Kramer post hoc test; $n=4$ ).

fate of any given MN (Oppenheim, 1991; Pettmann and Henderson, 1998; Raoul et al., 2000; Ricart et al., 2006). Thus, augmenting the target size (or provision of MNs with increasing amounts of MEx) may result in the increased availability of both trophic and toxic factors, thereby making the rescue of all MNs impossible. Our data are consistent with both of these alternatives. We provide data indicating that the target produces a factor leading to the death of a subset of MNs in a manner dependent on signaling through the p $75^{\mathrm{NT}}$ receptor and caspase 3/7 activation. We also show that astrocytes are a potent source of trophic support for MNs in vitro and during developmental and induced PCD in ovo. Moreover, our results indicate that astrocyte-secreted factors can promote MN survival to a greater extent than those derived from muscles, and that astrocytes and to a lesser extent the target, may contribute to the development of MN target independence.

\section{Trophic sources for MNs}

The PCD of lumbar MNs occurs between E5 and E12 in the chick nervous system and results in the loss of $40-50 \%$ of the original MN population. The most common hypothesis underlying the survival of MNs during PCD is that these cells compete successfully for limited amounts of trophic factor from the target, whereas the cells that lose in this competition ultimately die (Cunningham, 1982; Oppenheim, 1991; Sendtner et al., 2000; Yuan and Yankner, 2000). Underscoring the critical nature of the target in the regulation of $\mathrm{MN}$ survival are studies in which the unilateral extirpation of a limb results in the loss of nearly ( $\sim 90 \%$ ) all of the MNs ipsilateral to the lesion. Conversely, augmentation of the target through the addition of a supernumerary limb results in the partial rescue of MNs from PCD. Findings that protein extracts derived from the muscle (e.g., MEx and MCM) contain numerous putative MN trophic factors and rescue significant numbers of MNs from PCD in vitro and in vivo provide additional support for the importance of the target as a source of trophic support.

Despite these findings, several studies indicate that the target is not the sole source of trophic support for MNs throughout their life. For example, $10 \%$ of MNs survive after LBR, suggesting that a subpopulation of cells is either trophic independent or obtains trophic support from alternative sources (Caldero et al., 1998). Moreover, although LBR is performed before the onset of naturally occurring PCD, death that occurs as a result of this manipulation does not ensue until the normal period of PCD, suggesting there is a period of time before the onset of PCD during which MNs survive in the absence of target-derived trophic support (Oppenheim et al., 1978). MNs die in animals subjected to embryological or neonatal axotomy or nerve crush; however, these cells are relatively spared later postnatally, implying that $\mathrm{MN}$ target dependence declines with age (Crews and Wigston, 1990; Kuno, 1990; Oppenheim et al., 1990; Lowrie and Vrbova, 1992; Houenou et al., 1994). 


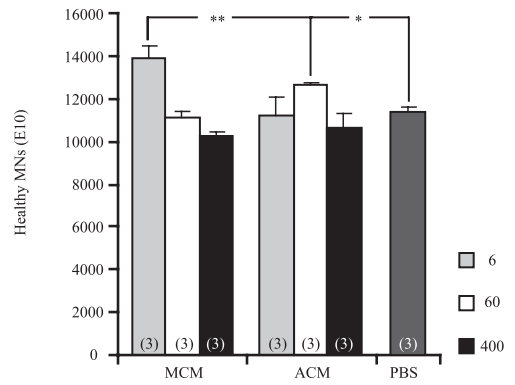

Figure 7. $A C M$ and MCM prevent MN PCD in ovo. Treatment with $6 \mu \mathrm{g} / \mathrm{ml} \mathrm{MCM}$ or $60 \mu \mathrm{g} / \mathrm{ml}$ $A C M$ results in the significant increase in healthy MNs after PCD in ovo (E10). Treatment with MCM resulted in a dose-dependent decrease in $\mathrm{MN}$ survival, similar to that seen in vitro. In ovo treatment with ACM also resulted in an increase in the number of healthy MNs, but a higher concentration of ACM was required to achieve this result $(60 \mu \mathrm{g} / \mathrm{ml})$. The numbers in parentheses indicate $n$ for each group $\left({ }^{*} p<0.05,{ }^{* *} p<0.01\right.$; ANOVA with Tukey-Kramer post hoc analysis).
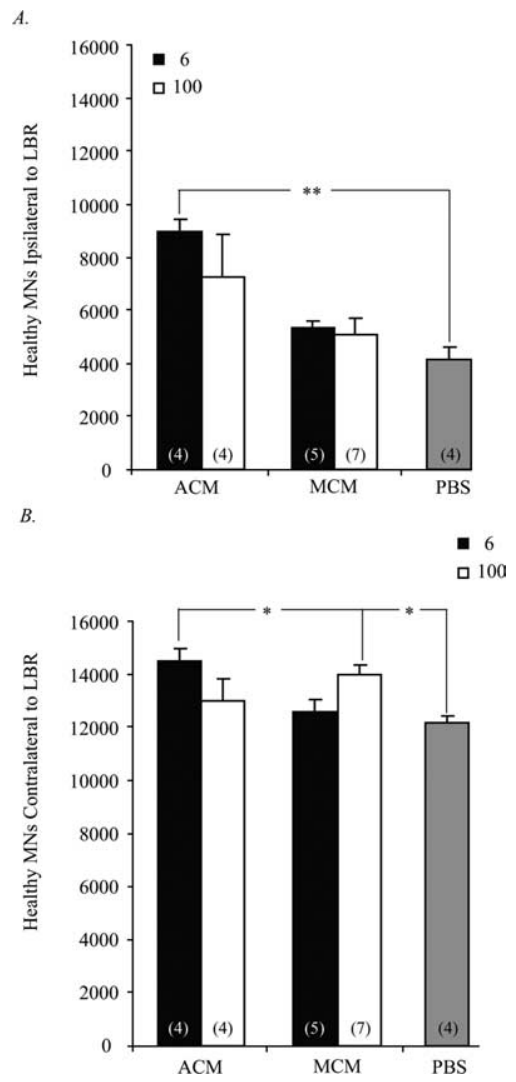

Figure 8. $A C M$, but not $M C M$, rescues MNs from unilateral LBR. $A$, Treatment with $6 \mu \mathrm{g} / \mathrm{ml}$ ACM resulted in the significant increase in healthy MNs (E8) ipsilateral to unilateral LBR. $\boldsymbol{B}$, Although MCM was unable to rescue MNs after LBR, it was able to rescue a significant number of MNs from PCD (as was $A C M$ ) as indicated by the internal control contralateral to the lesion. The numbers in parentheses indicate $n$ for each condition $\left({ }^{*} p<0.05,{ }^{* *} p<0.01\right.$; ANOVA with Tukey-Kramer post hoc analysis).

In addition to the muscle, other cellular populations have been implicated in the support of MN survival (e.g., Schwann cells, astrocytes, afferents, components of the extracellular matrix). Schwann cells produce many of the trophic factors used by MNs, including GDNF, and CNTF (Friedman et al., 1992; Masu et al., 1993; Henderson et al., 1994; Lee et al., 1995). In mice lacking the ErbB3 receptor, Schwann-cell precursors and their mature counterparts fail to develop. Despite this, MNs initially develop normally, although at later stages of development, $\sim 80 \%$ of MNs die. (Riethmacher et al., 1997). Similar findings were demonstrated after the deletion of the ErbB2 receptor (Morris et al., 1999). Adult MNs are relatively spared when they are axotomized; however, this is not the case after spinal root avulsion, an injury that is more proximal to the cell body, a finding that may be partially attributable to the increased Schwann cell loss that occurs as a result of this injury (Wu et al., 2003).

In chick embryos subjected to deafferentation, MNs can be rescued by astrocyte-derived factors, as can MNs in vitro (Eagleson et al., 1985; Yin et al., 1994). Our data provide additional evidence in support of astrocytes as a major source of trophic support for developing and injured MNs. We show that astrocytes significantly rescue MNs from death in vitro and from naturally occurring PCD in ovo. Furthermore, ACM is one of a select group of agents (including MEx and GDNF) capable of rescuing MNs from death that results after LBR (Caldero et al., 1998). Although astrocytes are potent sources of GDNF, the rescue of MNs by ACM is likely not a result of astrocyte-derived GDNF, because utilization of antibodies that neutralize the function of this protein or its receptor GFR $\alpha 1$ fail to significantly reduce the survival-promoting effects of ACM on MNs in vitro (data not shown) (Gould and Oppenheim, 2004; Zhou et al., 2005). Moreover, although astrocytes produce numerous other trophic factors that support MN survival, and it is likely that a significant portion of the survival-promoting abilities of ACM are attributable to the presence of some of these factors, utilization of varying concentrations of neutralizing antibodies to NGF, NT3, and BDNF also fail to reduce the survival promoting activity of ACM (data not shown) (Muller et al., 1995; Tfelt-Hansen et al., 2004; Kimura et al., 2006). Interestingly, none of these factors when administered in singular or in combination promote MN survival to the same extent as ACM in vitro or after LBR in ovo. Together, these data suggest the possible presence of novel astrocyte-derived trophic agents or of known proteins with novel functions. Current studies are underway in our laboratory to identify some of these factors.

When MNs are cultured with ACM for $2 \mathrm{~d}$ and then cultured in the absence of trophic factor, the majority $(\sim 75 \%)$ of MNs survive. These results suggest that astrocyte factors may contribute to the development of MN target independence. Although the target may also contribute to this event (55 and 40\% of MNs survive when initially exposed to MCM and MEx), it is noteworthy that there is a strong temporal correlation with MN target independence and with the appearance of GFAPimmunoreactive astrocytes in the chick spinal cord (Bignami and Dahl, 1975; Dahl and Bignami, 1975; Houenou et al., 1994).

\section{Production of pro-apoptotic signals by the target}

As the neurotrophic hypothesis posits that neurons are required to obtain trophic support or risk death, the implication is that survival is an active process, and death occurs as the result of a default mechanism. Although the trophic benefits of the target are without question, recent evidence suggests that the target may also provide MNs with noxious signals leading to their demise (Oppenheim, 1991; Pettmann and Henderson, 1998; Raoul et al., 2000; Ricart et al., 2006). As discussed previously, the addition of a supernumerary limb results in a significant increase in $\mathrm{MN}$ survival. If, however, MN number directly reflects the size of the target, then it is anticipated that an additional limb would effectively double the MN population. In fact, only a $20 \%$ increase in the number of surviving MNs results, although this result could be attributable to incomplete innervation of the added limb (Hollyday and Hamburger, 1976). An increase in MN number 
also results following both the pharmacological blockade of muscle activity as well as the genetic deletion of rapsyn, MuSK (muscle-specific kinase), and ChAT (cholineacetyltransferase), proteins critical for the formation of a functional NMJ (Pittman and Oppenheim, 1978; Pittman and Oppenheim, 1979; Oppenheim et al., 2000, 2003; Banks et al., 2001, 2003; Terrado et al., 2001; Banks and Noakes, 2002; Misgeld et al., 2002; Brandon et al., 2003). These findings imply that the inhibition of a primary function of the target enhances its capacity to support neuronal survival superseding that which occurs during normal development when such inhibition is not present. We have shown that astrocytes provide a potent source of $\mathrm{MN}$ trophic support in vitro and in vivo in the absence of the target; however, during the period of naturally occurring PCD, this effect is less profound. These data may indicate that in the presence of putative targetderived pro-apoptotic factors, astrocyte factors are less effective; however, removal of this negative signal may provide a more permissive environment for astrocytes to exert their influence. This is further supported by our findings that, after LBR, ipsilateral MNs are rescued by astrocyte-derived factors but not muscle-derived factors, but MNs contralateral to the injury are rescued by both muscle- and astrocyte-derived factors. It is clear that although the target is essential for neuronal survival, failure to successfully acquire trophic support may not be the only explanation for neuronal death (Cunningham, 1982).

Our data indicate that although secreted factors from the muscle support $\mathrm{MN}$ survival in vitro and in vivo, other factors in MCM lead to the death of a subpopulation of MNs in a manner dependent on the activation of p75 ${ }^{\text {NTR }}$ and caspase $3 / 7$. MCMinduced death appears to occur in a context-dependent manner, as MNs matured in ACM no longer die in response to it. Moreover, maturation of MNs appears to alter their requirements for p $75^{\text {NTR }}$ such that the survival of MNs treated with ACM and MCM is reduced by nearly $50 \%$ with blockade of $\mathrm{p} 75^{\mathrm{NTR}}$, suggesting that this receptor becomes critical for $\mathrm{MN}$ survival rather than death.

The role of $\mathrm{p} 75^{\mathrm{NTR}}$ during development is complex and differs between neuronal populations (Lee et al., 1992; Davies et al., 1993; Barker, 1998; Miller and Kaplan, 1998). In p75 ${ }^{\text {NTR }}$-null mice, the normal period of ganglion cell death in the retina is delayed (Frade and Barde, 1999; Harada et al., 2006). This is also thought to be the case for sympathetic neurons, because neuronal survival during this period appears to be dictated by the relative levels of activated trkA versus p75 ${ }^{\text {NTR }}$ (Bamji et al., 1998). Furthermore, in DRG neurons, the function of $\mathrm{p} 75^{\mathrm{NTR}}$ appears to be developmentally regulated, being required for neuronal survival during early development and dispensable at postnatal ages (Barrett and Bartlett, 1994). The role of $\mathrm{p} 75^{\mathrm{NTR}}$ in MN development is less clear. During development, a reduction of lumbar (tibial) and facial MNs has been documented in $\mathrm{p} 75^{\mathrm{NTR}}(-/-)$ mice; however, a similar reduction is not observed in brachial spinal MNs (Frade and Barde, 1999; Wiese et al., 1999; Boyd and Gordon, 2001). Moreover, in p75 ${ }^{\mathrm{NTR}}$ mutants that express only the intracellular domain (acting as a constitutive activator), no developmental loss of MNs in the facial nucleus is observed (Majdan et al., 1997). From these studies, one would predict that the absence of $\mathrm{p} 75^{\mathrm{NTR}}$ during development would result either in reduced or unaltered $\mathrm{MN}$ survival; a finding that is contradictory to our own. Although the precise reason for this discrepancy is unclear, recent studies indicate that $\mathrm{p} 75 \mathrm{NTR}^{\text {ExonIII-/- }}$ mice (the genotype used in the previously mentioned studies) express a potentially active, alternatively spliced form of $\mathrm{p} 75^{\mathrm{NTR}}$ (von Schack et al., 2001). Attempts to rectify this resulted in the pro- duction of a p75NTR ${ }^{\text {ExonIV-/- }}$ mouse, which has subsequently been shown to express a pro-apoptotic fragment, which may reflect a gain-of-function mutation rather than a loss of function (Paul et al., 2004). Because of these technical challenges as well as the constitutive deletion of a protein that is critical for multiple developmental processes (e.g., dendritic development, neurite outgrowth, and myoblast survival), it is difficult to make any strong conclusions regarding the role of $\mathrm{p} 75^{\mathrm{NTR}}$ in the survival or death of MNs during development (Reddypalli et al., 2005; Salama-Cohen et al., 2005).

Not only can $\mathrm{p} 75^{\mathrm{NTR}}$ interact with multiple ligands (e.g., NGF, BDNF, NT-3/NT-4, MAG, and Nogo), it can use several coreceptors to exert its biological influence (e.g., TrkA, TrkB, TrkC, Sortilin, Nogo-R, and Lingo) (Dechant and Barde, 2002; Barker, 2004; Bronfman and Fainzilber, 2004; Lu et al., 2005; Nykjaer et al., 2005). Recent studies have suggested that signaling through the $\mathrm{p} 75^{\mathrm{NTR}} /$ Sortilin receptor complex by proneurotrophins (e.g., proNGF and proBDNF) may result in neuronal death in vitro and after CNS injury (Bamji et al., 1998; Lee et al., 2001; Boyd and Gordon, 2002; Harrington et al., 2004; Nykjaer et al., 2005; Teng et al., 2005; Volosin et al., 2006). Similar mechanisms may mediate the death-promoting effects of proNT-3, although death induced by this mechanism is less thoroughly documented (Giehl et al., 2001). The complexity of the context-dependent effects of $\mathrm{p} 75^{\mathrm{NTR}}$ on MN survival was recently discussed in a study suggesting that treatment of trophic factor-deprived MNs with $\beta$-neuregulin in combination with a neurotrophin results in p75 ${ }^{\mathrm{NTR}}$-dependent MNs death, whereas treatment with either neurotrophin or $\beta$-neuregulin alone resulted in enhanced MN survival (Ferri et al., 1998; Wiese et al., 1999; Boyd and Gordon, 2001; Ricart et al., 2006). Furthermore, although it has been suggested that MN survival as a result of activity blockade is a function of increased access to trophic factors resulting from an increase in sprouting or synapse number, it is interesting to note that activity blockade (which results in enhanced MN survival) leads to the downregulation of $\beta$-neuregulin, which may lead to enhanced utilization of neurotrophins by MNs (Loeb and Fischbach, 1997; Loeb et al., 2002). Together, these findings suggest a mechanism by which neuregulins and neurotrophins antagonize one another through two receptor complexes to regulate $\mathrm{MN}$ survival.

Although the discussion of a target-derived noxious signal has focused on $\mathrm{p} 75^{\mathrm{NTR}}$, it is important to note that this is likely not the sole death-inducing signal in MCM. Whereas a population of MCM-treated MNs in vitro is rescued via blockade of $\mathrm{p} 75^{\mathrm{NTR}}$, this rescue does not increase the survival of MNs to the extent seen after treatment with ACM. Alternatively, this could reflect the higher inherent capacity of ACM in promoting the survival of trophic factor-deprived MNs. Nevertheless, both of our findings and those of others indicate that target-derived protein (e.g., MEx and MCM) mixtures can be toxic to MNs at high doses, suggesting that they may contain factors that can be overcome at low doses by the presence of trophic factors but that become insurmountable at higher doses (Henderson et al., 1984). On a more global scale, these data suggest that MN survival after PCD may not be just a competition for limiting amounts of trophic support, but may also be the result of a surviving cell receiving more trophic than toxic signal. Thus, a balance of trophic and toxic target-derived signals, and not the access of MNs to it, may ultimately dictate whether any given cell will live or die. As MNs undergo a discrete period of PCD and remaining cells are maintained into adulthood, it is conceivable that MNs are only competent to receive a death signal during this stage of development 
based on the limited availability of this signal, or an alteration of its receptor expression or accessibility.

\section{Conclusions}

Together, our data highlight not only the possibility that proapoptotic signals originate from the target, they implicate astrocytes as a critical source for MN trophic support. It is unclear when astrocyte trophic support becomes critical for MN survival; however, it is interesting to note that there is a strong temporal correlation with MN target independence (E12 in the chick embryo), and the appearance of GFAP-positive astrocytes (Bignami and Dahl, 1975; Tapscott et al., 1981; Houenou et al., 1994; Oppenheim et al., 1995). These data suggest that this population of cells may become essential during adulthood, and that their dysregulation may strongly contribute to neurodegenerative conditions, including amyotrophic lateral sclerosis (Cleveland and Rothstein, 2001; Barbeito et al., 2004).

\section{References}

Arce V, Pollock RA, Philippe JM, Pennica D, Henderson CE, deLapeyriere O (1998) Synergistic effects of schwann- and muscle-derived factors on motoneuron survival involve GDNF and cardiotrophin-1 (CT-1). J Neurosci 18:1440-1448.

Bamji SX, Majdan M, Pozniak CD, Belliveau DJ, Aloyz R, Kohn J, Causing CG, Miller FD (1998) The p75 neurotrophin receptor mediates neuronal apoptosis and is essential for naturally occurring sympathetic neuron death. J Cell Biol 140:911-923.

Banks GB, Noakes PG (2002) Elucidating the molecular mechanisms that underlie the target control of motoneuron death. Int J Dev Biol 46:551-558.

Banks GB, Chau TN, Bartlett SE, Noakes PG (2001) Promotion of motoneuron survival and branching in rapsyn-deficient mice. J Comp Neurol 429:156-165.

Banks GB, Choy PT, Lavidis NA, Noakes PG (2003) Neuromuscular synapses mediate motor axon branching and motoneuron survival during the embryonic period of programmed cell death. Dev Biol 257:71-84.

Barbeito LH, Pehar M, Cassina P, Vargas MR, Peluffo H, Viera L, Estevez AG, Beckman JS (2004) A role for astrocytes in motor neuron loss in amyotrophic lateral sclerosis. Brain Res Brain Res Rev 47:263-274.

Barker PA (1998) p75NTR: A study in contrasts. Cell Death Differ 5:346-356.

Barker PA (2004) p75NTR is positively promiscuous: novel partners and new insights. Neuron 42:529-533.

Barrett GL, Bartlett PF (1994) The p75 nerve growth factor receptor mediates survival or death depending on the stage of sensory neuron development. Proc Natl Acad Sci USA 91:6501-6505.

Bignami A, Dahl D (1975) Astroglial protein in the developing spinal cord of the chick embryo. Dev Biol 44:204-209.

Bloch-Gallego E, Huchet M, el M'Hamdi H, Xie FK, Tanaka H, Henderson CE (1991) Survival in vitro of motoneurons identified or purified by novel antibody-based methods is selectively enhanced by muscle-derived factors. Development 111:221-232.

Boyd JG, Gordon T (2001) The neurotrophin receptors, trkB and p75, differentially regulate motor axonal regeneration. J Neurobiol 49:314-325.

Boyd JG, Gordon T (2002) A dose-dependent facilitation and inhibition of peripheral nerve regeneration by brain-derived neurotrophic factor. Eur J Neurosci 15:613-626.

Brandon EP, Lin W, D'Amour KA, Pizzo DP, Dominguez B, Sugiura Y, Thode S, Ko CP, Thal LJ, Gage FH, Lee KF (2003) Aberrant patterning of neuromuscular synapses in choline acetyltransferase-deficient mice. J Neurosci 23:539-549.

Bronfman FC, Fainzilber M (2004) Multi-tasking by the p75 neurotrophin receptor: sortilin things out? EMBO Rep 5:867-871.

Caldero J, Prevette D, Mei X, Oakley RA, Li L, Milligan C, Houenou L, Burek M, Oppenheim RW (1998) Peripheral target regulation of the development and survival of spinal sensory and motor neurons in the chick embryo. J Neurosci 18:356-370.

Calof AL, Reichardt LF (1984) Motoneurons purified by cell sorting respond to two distinct activities in myotube-conditioned medium. Dev Biol 106:194-210.
Cassina P, Pehar M, Vargas MR, Castellanos R, Barbeito AG, Estevez AG, Thompson JA, Beckman JS, Barbeito L (2005) Astrocyte activation by fibroblast growth factor-1 and motor neuron apoptosis: implications for amyotrophic lateral sclerosis. J Neurochem 93:38-46.

Chu-Wang IW, Oppenheim RW (1978) Cell death of motoneurons in the chick embryo spinal cord. II. A quantitative and qualitative analysis of degeneration in the ventral root, including evidence for axon outgrowth and limb innervation prior to cell death. J Comp Neurol 177:59-85.

Clarke PG, Oppenheim RW (1995) Neuron death in vertebrate development: in vitro methods. Methods Cell Biol 46:277-321.

Cleveland DW, Rothstein JD (2001) From Charcot to Lou Gehrig: deciphering selective motor neuron death in ALS. Nat Rev Neurosci 2:806-819.

Crews LL, Wigston DJ (1990) The dependence of motoneurons on their target muscle during postnatal development of the mouse. J Neurosci 10:1643-1653.

Cunningham TJ (1982) Naturally occurring neuron death and its regulation by developing neural pathways. Int Rev Cytol 74:163-186.

Curtis R, Tonra JR, Stark JL, Adryan KM, Park JS, Cliffer KD, Lindsay RM, DiStefano PS (1998) Neuronal injury increases retrograde axonal transport of the neurotrophins to spinal sensory neurons and motor neurons via multiple receptor mechanisms. Mol Cell Neurosci 12:105-118.

Dahl D, Bignami A (1975) Glial fibrillary acidic protein from normal and gliosed human brain. Demonstration of multiple related polypeptides. Biochim Biophys Acta 386:41-51.

Davies AM, Lee KF, Jaenisch R (1993) p75-deficient trigeminal sensory neurons have an altered response to NGF but not to other neurotrophins. Neuron 11:565-574.

Dechant G, Barde YA (2002) The neurotrophin receptor p75(NTR): novel functions and implications for diseases of the nervous system. Nat Neurosci 5:1131-1136.

Della-Bianca V, Rossi F, Armato U, Dal-Pra I, Costantini C, Perini G, Politi V, Della Valle G (2001) Neurotrophin p75 receptor is involved in neuronal damage by prion peptide-(106-126). J Biol Chem 276:38929-38933.

Dowling P, Ming X, Raval S, Husar W, Casaccia-Bonnefil P, Chao M, Cook S, Blumberg B (1999) Up-regulated p75NTR neurotrophin receptor on glial cells in MS plaques. Neurology 53:1676-1682.

Eagleson KL, Bennett MR (1986) Motoneurone survival requirements during development: the change from immature astrocyte dependence to myotube dependence. Brain Res 394:161-172.

Eagleson KL, Raju TR, Bennett MR (1985) Motoneurone survival is induced by immature astrocytes from developing avian spinal cord. Brain Res 349:95-104.

Ericson J, Thor S, Edlund T, Jessell TM, Yamada T (1992) Early stages of motor neuron differentiation revealed by expression of homeobox gene Islet-1. Science 256:1555-1560.

Ernfors P, Henschen A, Olson L, Persson H (1989) Expression of nerve growth factor receptor mRNA is developmentally regulated and increased after axotomy in rat spinal cord motoneurons. Neuron 2:1605-1613.

Ferri CC, Moore FA, Bisby MA (1998) Effects of facial nerve injury on mouse motoneurons lacking the p75 low-affinity neurotrophin receptor. J Neurobiol 34:1-9.

Frade JM, Barde YA (1999) Genetic evidence for cell death mediated by nerve growth factor and the neurotrophin receptor p75 in the developing mouse retina and spinal cord. Development 126:683-690.

Frade JM, Rodriguez-Tebar A, Barde YA (1996) Induction of cell death by endogenous nerve growth factor through its p75 receptor. Nature 383:166-168

Friedman B, Scherer SS, Rudge JS, Helgren M, Morrisey D, McClain J, Wang DY, Wiegand SJ, Furth ME, Lindsay RM, et al (1992) Regulation of ciliary neurotrophic factor expression in myelin-related Schwann cells in vivo. Neuron 9:295-305.

Furber S, Oppenheim RW, Prevette D (1987) Naturally-occurring neuron death in the ciliary ganglion of the chick embryo following removal of preganglionic input: evidence for the role of afferents in ganglion cell survival. J Neurosci 7:1816-1832.

Giehl KM, Rohrig S, Bonatz H, Gutjahr M, Leiner B, Bartke I, Yan Q, Reichardt LF, Backus C, Welcher AA, Dethleffsen K, Mestres P, Meyer M (2001) Endogenous brain-derived neurotrophic factor and neurotrophin-3 antagonistically regulate survival of axotomized corticospinal neurons in vivo. J Neurosci 21:3492-3502.

Giraud S, Lautrette C, Bessette B, Decourt C, Mathonnet M, Jauberteau MO 
(2005) Modulation of Fas-induced apoptosis by p75 neurotrophin receptor in a human neuroblastoma cell line. Apoptosis 10:1271-1283.

Gould TW, Oppenheim RW (2004) The function of neurotrophic factor receptors expressed by the developing adductor motor pool in vivo. J Neurosci 24:4668-4682.

Grieshammer U, Lewandoski M, Prevette D, Oppenheim RW, Martin GR (1998) Muscle-specific cell ablation conditional upon Cre-mediated DNA recombination in transgenic mice leads to massive spinal and cranial motoneuron loss. Dev Biol 197:234-247.

Hamburger V, Hamilton H (1951) A series of normal stages in the development of the chick embryo. J Morphology 88:49-92.

Harada C, Harada T, Nakamura K, Sakai Y, Tanaka K, Parada LF (2006) Effect of p75NTR on the regulation of naturally occurring cell death and retinal ganglion cell number in the mouse eye. Dev Biol 290:57-65.

Harrington AW, Leiner B, Blechschmitt C, Arevalo JC, Lee R, Morl K, Meyer M, Hempstead BL, Yoon SO, Giehl KM (2004) Secreted proNGF is a pathophysiological death-inducing ligand after adult CNS injury. Proc Natl Acad Sci USA 101:6226-6230.

Henderson CE, Huchet M, Changeux JP (1981) Neurite outgrowth from embryonic chicken spinal neurons is promoted by media conditioned by muscle cells. Proc Natl Acad Sci USA 78:2625-2629.

Henderson CE, Huchet M, Changeux JP (1984) Neurite-promoting activities for embryonic spinal neurons and their developmental changes in the chick. Dev Biol 104:336-347.

Henderson CE, Phillips HS, Pollock RA, Davies AM, Lemeulle C, Armanini M, Simmons L, Moffet B, Vandlen RA, Simpson LC, et al (1994) GDNF: a potent survival factor for motoneurons present in peripheral nerve and muscle. Science 266:1062-1064.

Henderson CE, Yamamoto Y, Livet J, Arce V, Garces A, deLapeyriere O (1998) Role of neurotrophic factors in motoneuron development. J Physiol Paris 92:279-281.

Hollyday M, Hamburger V (1976) Reduction of the naturally occurring motor neuron loss by enlargement of the periphery. J Comp Neurol 170:311-320.

Houenou LJ, Li L, Lo AC, Yan Q, Oppenheim RW (1994) Naturally occurring and axotomy-induced motoneuron death and its prevention by neurotrophic agents: a comparison between chick and mouse. Prog Brain Res 102:217-226.

Kablar B, Rudnicki MA (1999) Development in the absence of skeletal muscle results in the sequential ablation of motor neurons from the spinal cord to the brain. Dev Biol 208:93-109.

Kimura N, Takahashi M, Tashiro T, Terao K (2006) Amyloid beta upregulates brain-derived neurotrophic factor production from astrocytes: Rescue from amyloid beta-related neuritic degeneration. J Neurosci Res.

Kuno M (1990) Target dependence of motoneuronal survival: the current status. Neurosci Res 9:155-172.

Lafon-Cazal M, Adjali O, Galeotti N, Poncet J, Jouin P, Homburger V, Bockaert J, Marin P (2003) Proteomic analysis of astrocytic secretion in the mouse. Comparison with the cerebrospinal fluid proteome. J Biol Chem 278:24438-24448.

Lambert C, Landau AM, Desbarats J (2003) Fas-beyond death: a regenerative role for Fas in the nervous system. Apoptosis 8:551-562.

Lee DA, Zurawel RH, Windebank AJ (1995) Ciliary neurotrophic factor expression in Schwann cells is induced by axonal contact. J Neurochem 65:564-568.

Lee KF, Li E, Huber LJ, Landis SC, Sharpe AH, Chao MV, Jaenisch R (1992) Targeted mutation of the gene encoding the low affinity NGF receptor p75 leads to deficits in the peripheral sensory nervous system. Cell 69:737-749.

Lee R, Kermani P, Teng KK, Hempstead BL (2001) Regulation of cell survival by secreted proneurotrophins. Science 294:1945-1948.

Levison S, McCarthy KD (1991) Astroglia in culture. In: Culturing nerve cells (Banker GA, ed), pp 309-336. Cambridge: MIT Press.

Loeb JA, Fischbach GD (1997) Neurotrophic factors increase neuregulin expression in embryonic ventral spinal cord neurons. J Neurosci $17: 1416-1424$.

Loeb JA, Hmadcha A, Fischbach GD, Land SJ, Zakarian VL (2002) Neuregulin expression at neuromuscular synapses is modulated by synaptic activity and neurotrophic factors. J Neurosci 22:2206-2214.

Lowrie MB, Vrbova G (1992) Dependence of postnatal motoneurones on their targets: review and hypothesis. Trends Neurosci 15:80-84.
Lu B, Pang PT, Woo NH (2005) The yin and yang of neurotrophin action. Nat Rev Neurosci 6:603-614.

Majdan M, Lachance C, Gloster A, Aloyz R, Zeindler C, Bamji S, Bhakar A, Belliveau D, Fawcett J, Miller FD, Barker PA (1997) Transgenic mice expressing the intracellular domain of the p75 neurotrophin receptor undergo neuronal apoptosis. J Neurosci 17:6988-6998.

Masu Y, Wolf E, Holtmann B, Sendtner M, Brem G, Thoenen H (1993) Disruption of the CNTF gene results in motor neuron degeneration. Nature 365:27-32.

McKay SE, Garner A, Caldero J, Tucker RP, Large T, Oppenheim RW (1996) The expression of trkB and p75 and the role of BDNF in the developing neuromuscular system of the chick embryo. Development 122:715-724.

Michler-Stuke A, Bottenstein JE (1982) Proliferation of glial-derived cells in defined media. J Neurosci Res 7:215-228.

Miller FD, Kaplan DR (1998) Life and death decisions: a biological role for the p75 neurotrophin receptor. Cell Death Differ 5:343-345.

Milligan CE, Oppenheim RW, Schwartz LM (1994) Motoneurons deprived of trophic support in vitro require new gene expression to undergo programmed cell death. J Neurobiol 25:1005-1016.

Misgeld T, Burgess RW, Lewis RM, Cunningham JM, Lichtman JW, Sanes JR (2002) Roles of neurotransmitter in synapse formation: development of neuromuscular junctions lacking choline acetyltransferase. Neuron 36:635-648.

Morris JK, Lin W, Hauser C, Marchuk Y, Getman D, Lee KF (1999) Rescue of the cardiac defect in ErbB2 mutant mice reveals essential roles of ErbB2 in peripheral nervous system development. Neuron 23:273-283.

Muller HW, Junghans U, Kappler J (1995) Astroglial neurotrophic and neurite-promoting factors. Pharmacol Ther 65:1-18.

Neville C, Rosenthal N, McGrew M, Bogdanova N, Hauschka S (1998) Skeletal muscle cultures. In: Methods in muscle biology, pp 85-114. San Diego: Academic.

Newbern J, Taylor A, Robinson M, Li L, Milligan CE (2005) Decreases in phosphoinositide-3-kinase/Akt and extracellular signal-regulated kinase $1 / 2$ signaling activate components of spinal motoneuron death. J Neurochem 94:1652-1665.

Nishi R (1994) Neurotrophic factors: two are better than one. Science 265:1052-1053.

Nykjaer A, Willnow TE, Petersen CM (2005) p75NTR-live or let die. Curr Opin Neurobiol 15:49-57.

Okado N, Oppenheim RW (1984) Cell death of motoneurons in the chick embryo spinal cord. IX. The loss of motoneurons following removal of afferent inputs. J Neurosci 4:1639-1652.

Oppenheim RW (1991) Cell death during development of the nervous system. Annu Rev Neurosci 14:453-501.

Oppenheim RW (1996) Neurotrophic survival molecules for motoneurons: an embarrassment of riches. Neuron 17:195-197.

Oppenheim RW, Chu-Wang IW, Maderdrut JL (1978) Cell death of motoneurons in the chick embryo spinal cord. III. The differentiation of motoneurons prior to their induced degeneration following limb-bud removal. J Comp Neurol 177:87-111.

Oppenheim RW, Haverkamp LJ, Prevette D, McManaman JL, Appel SH (1988) Reduction of naturally occurring motoneuron death in vivo by a target-derived neurotrophic factor. Science 240:919-922.

Oppenheim RW, Prevette D, Tytell M, Homma S (1990) Naturally occurring and induced neuronal death in the chick embryo in vivo requires protein and RNA synthesis: evidence for the role of cell death genes. Dev Biol 138:104-113.

Oppenheim RW, Prevette D, Haverkamp LJ, Houenou L, Yin QW, McManaman J (1993) Biological studies of a putative avian muscle-derived neurotrophic factor that prevents naturally occurring motoneuron death in vivo. J Neurobiol 24:1065-1079.

Oppenheim RW, Houenou LJ, Johnson JE, Lin LF, Li L, Lo AC, Newsome AL, Prevette DM, Wang S (1995) Developing motor neurons rescued from programmed and axotomy-induced cell death by GDNF. Nature 373:344-346.

Oppenheim RW, Prevette D, D’Costa A, Wang S, Houenou LJ, McIntosh JM (2000) Reduction of neuromuscular activity is required for the rescue of motoneurons from naturally occurring cell death by nicotinic-blocking agents. J Neurosci 20:6117-6124.

Oppenheim RW, Caldero J, Cuitat D, Esquerda J, Ayala V, Prevette D, Wang S (2003) Rescue of developing spinal motoneurons from programmed cell death by the GABA(A) agonist muscimol acts by blockade of neuro- 
muscular activity and increased intramuscular nerve branching. Mol Cell Neurosci 22:331-343.

Paul CE, Vereker E, Dickson KM, Barker PA (2004) A pro-apoptotic fragment of the p75 neurotrophin receptor is expressed in p75NTRExonIV null mice. J Neurosci 24:1917-1923.

Pehar M, Cassina P, Vargas MR, Castellanos R, Viera L, Beckman JS, Estevez AG, Barbeito L (2004) Astrocytic production of nerve growth factor in motor neuron apoptosis: implications for amyotrophic lateral sclerosis. J Neurochem 89:464-473.

Petruzzelli G, Hughes WF (1989) Enhanced survival of motoneurons in the chick lateral motor column: effects of embryonic skeletal muscle extracts and myoblast-conditioned medium. Exp Cell Biol 57:125-130.

Pettmann B, Henderson CE (1998) Neuronal cell death. Neuron 20:633-647.

Phelan KA, Hollyday M (1991) Embryonic development and survival of brachial motoneurons projecting to muscleless chick wings. J Comp Neurol 311:313-320.

Pittman R, Oppenheim RW (1979) Cell death of motoneurons in the chick embryo spinal cord. IV. Evidence that a functional neuromuscular interaction is involved in the regulation of naturally occurring cell death and the stabilization of synapses. J Comp Neurol 187:425-446.

Pittman RH, Oppenheim RW (1978) Neuromuscular blockade increases motoneurone survival during normal cell death in the chick embryo. Nature 271:364-366.

Rabizadeh S, Oh J, Zhong LT, Yang J, Bitler CM, Butcher LL, Bredesen DE (1993) Induction of apoptosis by the low-affinity NGF receptor. Science 261:345-348.

Raoul C, Pettmann B, Henderson CE (2000) Active killing of neurons during development and following stress: a role for p75(NTR) and Fas? Curr Opin Neurobiol 10:111-117.

Reddypalli S, Roll K, Lee HK, Lundell M, Barea-Rodriguez E, Wheeler EF (2005) p75NTR-mediated signaling promotes the survival of myoblasts and influences muscle strength. J Cell Physiol 204:819-829.

Ricart K, Pearson RJ, Viera L, Cassina P, Kamaid A, Carroll SL, Estevez AG (2006) Interactions between beta-neuregulin and neurotrophins in motor neuron apoptosis. J Neurochem 97:222-233.

Riethmacher D, Sonnenberg-Riethmacher E, Brinkmann V, Yamaai T, Lewin GR, Birchmeier C (1997) Severe neuropathies in mice with targeted mutations in the ErbB3 receptor. Nature 389:725-730.

Robinson MB, Tidwell JL, Gould T, Taylor AR, Newbern JM, Graves J, Tytell M, Milligan CE (2005) Extracellular heat shock protein 70: a critical component for motoneuron survival. J Neurosci 25:9735-9745.

Salama-Cohen P, Arevalo MA, Meier J, Grantyn R, Rodriguez-Tebar A (2005) NGF controls dendrite development in hippocampal neurons by binding to p75NTR and modulating the cellular targets of Notch. Mol Biol Cell 16:339-347.

Sedel F, Bechade C, Triller A (1999) Nerve growth factor (NGF) induces motoneuron apoptosis in rat embryonic spinal cord in vitro. Eur J Neurosci 11:3904-3912.

Sendtner M, Holtmann B, Hughes RA (1996) The response of motoneurons to neurotrophins. Neurochem Res 21:831-841.

Sendtner M, Pei G, Beck M, Schweizer U, Wiese S (2000) Developmental motoneuron cell death and neurotrophic factors. Cell Tissue Res 301:71-84.

Smith RG, Appel SH (1983) Extracts of skeletal muscle increase neurite outgrowth and cholinergic activity of fetal rat spinal motor neurons. Science 219:1079-1081.

Snider WD, Thanedar S (1989) Target dependence of hypoglossal motor neurons during development in maturity. J Comp Neurol 279:489-498.

Tapscott SJ, Bennett GS, Toyama Y, Kleinbart F, Holtzer H (1981) Intermediate filament proteins in the developing chick spinal cord. Dev Biol 86:40-54.

Taylor AR, Prevette D, Urioste AS, Oppenheim RW, Milligan CE (2003)
Cell cycle events distinguish sensory neuronal death from motoneuron death as a result of trophic factor deprivation. Mol Cell Neurosci 24:323-339.

Teng HK, Teng KK, Lee R, Wright S, Tevar S, Almeida RD, Kermani P, Torkin R, Chen ZY, Lee FS, Kraemer RT, Nykjaer A, Hempstead BL (2005) ProBDNF induces neuronal apoptosis via activation of a receptor complex of p75NTR and sortilin. J Neurosci 25:5455-5463.

Terrado J, Monnier D, Perrelet D, Sagot Y, Mattenberger L, King B, Kato AC (2000) NGF-induced motoneuron cell death depends on the genetic background and motoneuron sub-type. NeuroReport 11:1473-1477.

Terrado J, Burgess RW, DeChiara T, Yancopoulos G, Sanes JR, Kato AC (2001) Motoneuron survival is enhanced in the absence of neuromuscular junction formation in embryos. J Neurosci 21:3144-3150.

Tfelt-Hansen J, Yano S, Bandyopadhyay S, Carroll R, Brown EM, Chattopadhyay N (2004) Expression of pituitary tumor transforming gene (PTTG) and its binding protein in human astrocytes and astrocytoma cells: function and regulation of PTTG in U87 astrocytoma cells. Endocrinology 145:4222-4231.

Troy CM, Friedman JE, Friedman WJ (2002) Mechanisms of p75-mediated death of hippocampal neurons. Role of caspases. J Biol Chem 277:34295-34302.

Turner BJ, Cheah IK, Macfarlane KJ, Lopes EC, Petratos S, Langford SJ, Cheema SS (2003) Antisense peptide nucleic acid-mediated knockdown of the p75 neurotrophin receptor delays motor neuron disease in mutant SOD1 transgenic mice. J Neurochem 87:752-763.

Volosin M, Song W, Almeida RD, Kaplan DR, Hempstead BL, Friedman WJ (2006) Interaction of survival and death signaling in basal forebrain neurons: roles of neurotrophins and proneurotrophins. J Neurosci 26:7756-7766.

von Bartheld CS, Kinoshita Y, Prevette D, Yin QW, Oppenheim RW, Bothwell M (1994) Positive and negative effects of neurotrophins on the isthmo-optic nucleus in chick embryos. Neuron 12:639-654.

von Schack D, Casademunt E, Schweigreiter R, Meyer M, Bibel M, Dechant G (2001) Complete ablation of the neurotrophin receptor p75NTR causes defects both in the nervous and the vascular system. Nat Neurosci 4:977-978.

Wang X, Bauer JH, Li Y, Shao Z, Zetoune FS, Cattaneo E, Vincenz C (2001) Characterization of a p75(NTR) apoptotic signaling pathway using a novel cellular model. J Biol Chem 276:33812-33820.

Wiese S, Metzger F, Holtmann B, Sendtner M (1999) The role of p75NTR in modulating neurotrophin survival effects in developing motoneurons. Eur J Neurosci 11:1668-1676.

Wong KC, Meyer T, Harding DI, Dick JR, Vrbova G, Greensmith L (1999) Integrins at the neuromuscular junction are important for motoneuron survival. Eur J Neurosci 11:3287-3292.

Wu W, Li L, Yick LW, Chai H, Xie Y, Yang Y, Prevette DM, Oppenheim RW (2003) GDNF and BDNF alter the expression of neuronal NOS, c-Jun, and p75 and prevent motoneuron death following spinal root avulsion in adult rats. J Neurotrauma 20:603-612.

Yan Q, Elliott JL, Matheson C, Sun J, Zhang L, Mu X, Rex KL, Snider WD (1993) Influences of neurotrophins on mammalian motoneurons in vivo. J Neurobiol 24:1555-1577.

Yin QW, Johnson J, Prevette D, Oppenheim RW (1994) Cell death of spinal motoneurons in the chick embryo following deafferentation: rescue effects of tissue extracts, soluble proteins, and neurotrophic agents. J Neurosci 14:7629-7640.

Yuan J, Yankner BA (2000) Apoptosis in the nervous system. Nature 407:802-809.

Zhou XF, Li WP, Zhou FH, Zhong JH, Mi JX, Wu LL, Xian CJ (2005) Differential effects of endogenous brain-derived neurotrophic factor on the survival of axotomized sensory neurons in dorsal root ganglia: a possible role for the p75 neurotrophin receptor. Neuroscience 132:591-603. 